\title{
DATA QUALITY PROBLEMS IN RESPONSIBILITY ACCOUNTING
}

\author{
Richard Calvasina, University of West Florida, Pensacola, FL, rcalvasi@uwf.edu \\ Eugene Calvasina, Southern University, Baton Rouge, LA, ejcalvasina@ cox.net \\ Mysore Ramaswamy, Southern University, Baton Rouge, LA, mysore@acm.org \\ Gerald Calvasina, Southern Utah University, Cedar City, UT, calvasina@suu.edu
}

\begin{abstract}
Innovations in information technology have affected all aspects of business including financial and managerial reporting. The quantity of information available is increasing exponentially. Simultaneously, it is becoming much easier to access these vast amounts of information. Unfortunately, in some cases, this information explosion has also made it harder to get the relevant and accurate information needed for good decision-making. The present day transactional engines generate abundant information. But we still observe problems in decision-making at higher levels of management. In spite of the tremendous increase in the available information for decision makers, some decisions at the strategic level turn out to be of poor quality. At the macro level, we find senior managers failing to seek answers for critical questions. At the micro level, we have not fully succeeded in monitoring the quality of the components that make the datainformation-decision chain. In this paper, we analyze some of the factors that are responsible data errors due to mistakes in coding procedures critical for financial and managerial reporting. We propose a data representation methodology that addresses this problem.
\end{abstract}

Keywords: Data Quality, Responsibility Accounting, Coding Scheme, Information Integrity

\section{INTRODUCTION}

Assuring the quality of information used in managerial decision-making has become a critical issue. Rockart [15] points out that in a majority of cases, information exists as 'islands' and these pieces are not linked to help effective decision-making. Traditionally, information systems have been designed to cater to the needs of managers at different levels of management. The advent of highly efficient transactional engines such as the ones used in Enterprise Resource Planning (ERP) systems has resulted in the availability of large quantities of information at the transactional level. The managers at the tactical and strategic levels are sometimes apprehensive about using these outputs of hardwired subsystems as they are not sure of the process logic [2]. For decision-making at higher levels of management, the information required has to be necessarily broad based.

In order to provide the proper information to management for decision making, it is necessary to start with the type of output management wants from the accounting system. In order to accomplish this task, the basic accounting system must be a perpetual inventory system on the accrual basis. With this basic system, transactions will be recorded appropriately as they occur. Unlike cash based periodic inventory system that record transactions only if they involve an actual cash inflow or cash outflow. One of the recent so called great improvements in accounting promulgated during the latter part of the 20th century was the Backflush Accounting System [1. 3. 4. 6]. Backflush, however, is nothing more than a fancy version of a periodic inventory system and as a result, companies that installed the system removed the accountants and the accounting system's ability to provide management with up-to-date information about inventories.

Rogers and Blenko [16] state the need to strike a balance between global and local considerations in the decision making process. Consistency errors can occur due to (a) data errors, (b) processing anomalies. Data errors can be minimized by strict monitoring of data quality. To address the issue of processing anomalies in different sources, we should adhere to a domain-specific data dictionary. Contemporary information systems such as enterprise resource planning (ERP) systems attempt to integrate all departments and functions across an organization into a single system that can serve the needs of all those different departments. Theoretically this should lead to cooperation between administrative agencies across organizational boundaries and even across hierarchical echelons [17]. But in many instances, information itself is the primary medium of value and exchange and sharing of such a powerful resource may result in complex mixture of conflict and cooperation between entities [10]. No doubt ERP systems are quite useful at the transactional level. But decision making process at the strategic level doesn't 
lend itself to integrate with the corporate template of ERP systems.

Enterprise Resource Planning (ERP) systems have been developed with the twin objectives of reducing operational costs and help make better quality managerial decision making. 'Work order' is the basic transaction upon which ERP implementations such as SAP have been built. As the production process progresses, the same system will link the consumption of inventory as well as track the production, shipping and accounts receivable [2]. The challenge to the management is to use the available information at the operational level for making decisions at the tactical and strategic levels. Undoubtedly, ERP systems provide vast amounts of information by utilizing their highly efficient transactional engines. The undesirable consequence is the greater degree of complexity in the decisionmaking process at the higher levels of management due to the increased volume of information available to managers. Because that information has been generated from a 'template' approach and does not differentiate between different types of data. Clearly, there is a need for an interface between transactional data / information and tactical decision-making. Galway and Hanks [5] categorize data into three groups: operational, conceptual, and organizational. Problems with operational data can occur due to missing data, invalid data, or inaccurate data. Conceptual data errors occur as a result of imprecise or ambiguous definition of data. Errors in organizational data occur due to disconnects between organizations that generate and/or use data.

Financial data stored in ledgers must be organized in a logical fashion. The most common way to do that is to use coding techniques. Coding is the systematic assignment of numbers or letters to items to classify and organize them $[7,8,9,13]$. Accuracy of this data representation directly impacts the usefulness of information systems built on these data. The thrust of this paper is to analyze the problem of this data representation technique in the contemporary business practice and suggest a methodology that will alleviate this problem. The rest of the paper is organized as follows. First, we introduce the coding schemes that are used for data representation. Subsequent sections describe the various aspects of the proposed coding methodology. Conclusions form the last section.

\section{ACCOUNTING INFORMATION SYSTEMS}

Data errors can have significant impact in all types of accounting systems. If the accounting information system is to provide both financial and internal reports, the coding scheme must be appropriately structured so that the data can be processed for financial and management reports. In order to do this, there must be at least three subsections to the coding scheme. If Activity Based Costing and Variable Costing are required additional coding subsections are required. The three basic subsections must include an identification code (ID), a general Ledger code (GL), and a Subsidiary Ledger code (SL). If Activity Based Costing (ABC) and Variable Costing (VC) are required, two more coding fields must be established. The three part basic coding scheme (ID, ABC, and SL) will provide the information for preparing the financial statements (Balance Sheet, Income Statement, and the Cash Flow Statement).

The primary source of the information to prepare the Balance Sheet and the Income Statement is the General Ledger and the control account balances contained within the General Ledger. The GL coding scheme organizes the accounts in the General Ledger with the Asset accounts first and ending with the Extraordinary Loss and Gain accounts found on the income statement. As a result, the Balance sheet and the Income Statement can be prepared, after adjusting entries have been prepared and posted to the general ledger, directly from the General Ledger.

The Cash Flow Statement preparation is another matter. It cannot be prepared directly from the General Ledger. To do it properly for management decision making requires Subsidiary Account coding of the cash account. This actually is quite easy as will be explained later in the paper.

For internal reporting the coding scheme is much more complex. Rather than reporting on the company in total, internal reports address subsections of the company and depending on the level of management that the report is intended, the level of detail increases as we go lower on the management chain. In order to provide the appropriate information for internal reports, responsibility for the transaction must be identified with the ID code. The ID code is must be based on an up to date and accurate Organization Chart. In order to provide the detail for the report, the SL coding scheme is required.

If there are other reporting needs, additional coding may be required. If the Organization Chart, for example, does not follow the specific activity breakdown of the company, and the company management wants to do Activity Based Costing 
( $\mathrm{ABC}$ ), an $\mathrm{ABC}$ coding scheme is required. If Variable Costing information is also requested, a Variable Cost identification code must be incorporated in the basic accounting code.

The normal coding scheme starts with the largest entity and goes to the smallest. As a result a typical coding scheme would have the ID code in the first field, the GL code in the second field, and the SL code in the third field. The number of digits in each category depends on the size and complexity of the business. However, one can provide all the information to create the financial statements for a General Motors size company with a simple three digit GL code. The management of General Motors, however, will not be able to run the company with just a GL coding scheme. They will simply not have the appropriate amount of detail in their reports nor the appropriate information by responsibility center to make informed business decisions to allow them to run their company successfully.

Various types of information of interest to management might include various types of sales information and various types of cost/spending information. Management would be interested in what products are selling; where those sales are being made, and who is buying their products. From a costing standpoint, retailers would want to match the cost of their products with revenues; manufacturers would want to know the efficiency with which they are making their products and the cost/spending involved. Both groups would want to know the inventories that they have not to mention the purchase orders for their products that they have on hand. These are just some of the information needs of the managers of various types of companies. The needs mentioned are not intended to be all encompassing. The proposed coding scheme focuses on an important attribute that affects the financial and managerial reporting and in no way does it violate any data normalization rules.

\section{IDENTIFICATION CODING}

In order to build the appropriate coding scheme for a company, one must start by asking a number of basic questions about the company. What is the company's primary type of business? Are they a retailer, a manufacturer, or a service company? Once that is determined, how are they organized? Are they centralized or are they set up in divisions? And finally, what type of information/reports does management want from the accounting system. While financial information is nice to know, a business cannot be run using financial data. Financial data/reports focus on the company in total and do not provide the detail needed for individual managers to run their departments or subsections of the business. If the accounting system is to be a management information system, it must identify the person responsible for the transaction and provide the necessary level of detail. In order to do this, the transaction data must be coded properly as it is being entered into the system. If it is not properly coded initially, the data must be recoded and reprocessed to obtain the reports and or answers to management's questions.

ID Coding is based on the Organization Chart for a company as indicated in Appendix I. The Rwood Company is a clothing manufacturer with a home office, and three manufacturing plants as indicated in Appendix I. At the home office, there are the offices for the company president, the vice presidents of marketing, manufacturing, personnel, and finance. Also at the home office are the company controller, the data processing staff, the marketing staff, and the purchasing department. Each plant is organized along the same lines. There is a plant manger, an accounting department, a payroll department, a data processing department, product design department, a customer service department, a personnel department, a production scheduling department, a raw material warehouse, a finished goods warehouse, and three production departments: cut, sew, and finish.

Part of the function of the organization chart is to show the lines of authority. All the departments at the plant level report to the plant manager. As a result, the coding scheme will identify the plant manager and eventually the vice president of production as responsible for all that occurs at the individual plants.

The ID Code for the Rwood Company would be at least 5 digits long. The first digit would identify the president as the ultimate authority or responsible person. The second digit would identify the individual vice-presidents. The third digit would identify the individual plants and home office staff. At the home office there are four service departments. The controller and data processing would report to the vice-president of finance while the marketing staff would report to the vice-president of marketing. The purchasing staff at the home office would report to the vice-president of production. The last two digits would identify the 12 departments reporting to the plant manager. 
An example of an ID code for a transaction involving the president's office would be 10000 . The one represents the president's office and the four zeros are written to let anyone know that the rest of the field has not been overlooked. For the vice president of manufacturing, assuming that the number one has been assigned

If a transaction involved a vice president directly, the second digit in the field would be utilized. Assuming that the vice-president of manufacturing has been assigned the number two, a transaction involving the vice-president of manufacturing's office would be coded. 02000. Again zeroes are written to indicate that no digits have been overlooked.

For a transaction involving one of the plant managers directly, the second and third digit would be utilized. The second digit would contain the number two to indicate that the plant manager reported to the vicepresident of manufacturing and then the third digit would indicted which plant manager was involved. If the transaction occurred for the plant manager of plant three, the code would be '02300.'

Since there are thirteen departments in each plant, to identify each department requires a two digit code. Assume that in plant three we have a transaction in the purchasing department and 07 is the code for this department. The ID Code for a transaction involving the purchasing department in plant three would be: 02307.

In summation, the first digit of the ID Code is for the president's office, the second digit is for the vicepresidents, the third digit identifies staff and plants, and the last two digits identify departments at the individual plants as indicated in Appendix II.

\section{GENERAL LEDGER CODING}

The GL part of the coding scheme is usually a three digit code that follows the normal sequence of accounts that is found in the general ledger. The general ledger usually starts with current assets than progresses through long-term assets, current liabilities, long-term liabilities, contributed and retained owner equity, sales, cost of sales, operating expenses, other gains and losses and finally extraordinary items. As indicated in Appendix III, the first digit of the three digit code identifies the class of account and the next two digits allow for up to ninety nine different accounts with in each section. Cash is usually the first account found in the general ledger. Current assets are also the first subsection of the general ledger. The GL Code for cash would be
101 since it is the first account in the first subsection of the general ledger. Sales are normally the sixth subsection of the general ledger. The cash gross sales account is the first account in this section. The GL Code for cash sales would be 601 since this account is the first account in the sixth subsection of the general ledger.

As indicated in Appendix III, the listing of subsections and the subsection numbers, assigned to each subsection is one of the more normal coding schemes. The nine subsections identified with the numbers 1 through 9, identify the appropriate subsection and the second and third digit allow for up to ninety nine accounts to be included in each subsection for a specific account such as Accounts Receivable in the Current Assets section of the general ledger.

\section{SUBSIDIARY LEDGER CODING}

In a fixed field coding scheme, the length of the subsidiary ledger code field is determined by the length of the largest subsidiary code. Two of the largest are usually the accounts receivable subsidiary ledger code and the finished goods inventory subsidiary ledger code. For example, for the Rwood Company plant 3 makes slips, half slips, muumuus, and peignoirs. While it may seem that we only need a one digit SL code because there are only 4 products, as indicated in Appendix IV, such is not the case. Each product has a 4 digit style code. They come in at least 3 different sizes, and they come in different colors. If there are less than 10 different colors for each product, the length of the SL code is going to need at least 7 digits. The first digit of the SL code for products will identify the product group. The next 4 digits will identify the style. Digit number 6 identifies the color, and finally digit number 7 identifies the size. If the product code for slips is "1" and the size code for white slips is "1" and for small slips the code is also "1", than for small white slip style number 2736, the SL code is 1273611. With this SL code for products, management can determine what they have in inventory and what products they have sold.

The sizes and colors used in Appendices V and VI are not meant to be all inclusive. Coding schemes for products depend on what the company is actually doing. The sizing may be numeric and as a result a different coding scheme must be employed. The same goes for the color code. Products may be in many more different colors than the three used in Appendix VI. 
If we were to record a sale of a small white slip, style number 2736 from Plant number 3's inventory, the code assigned to the sale would be 003006011273611. The ID code would identify Plant 3, the GL code (601) would identify the transaction as a sale. The SL code (1273611 would identify the product sold as a small white slip with the style number of 2736. If all that had been used was the GL code to record the sale, management would know the sales dollar amount but not what was sold. The detail needed for management planning and decision making would be lost in a financial approach black hole.

\section{CASH FLOW CODING}

The current approach by many of the electronic accounting software packages when preparing and presenting the Cash Flow Statement is as follows. The objective is to show the Indirect Method when presenting the Net Cash from Daily Operations. From a management perspective, the Indirect Method shows the correct total but not where the money has come from and where it has been spent. To show what is called the Direct Method of presenting the Net Cash from Daily Operations requires little more than setting up a subsidiary file for the Cash Account and a rather simple code. The Cash Flow Statement has three basic sections: Net Cash from Daily Operations; Net Cash from Investment Activities; and Net Cash from Financing Activities. Each basic section has two subsections: Cash Inflows and Cash Outflows. Within each subsection there can be more than 10 Cash Inflows or Cash Outflows. A four digit SL Code can organize the cash transaction as to their proper position on the cash flow statement. The first digit identifies the section of the statement to place the transaction (Operations, Investing, or Financing), the second digit identifies the subsection (Inflows or Outflows), and the last two digits identifies the type of transaction (Cash Sale, Accounts Receivable Payment, Payroll Payment, etc.). For a Cash Sale for a product from Plant 3 , the code for the transaction would be 003001011101. The ID code (00300) identifies the transaction as belonging to Plant 3 . The GL code (101) identifies the transaction as an entry into the Cash Account. The SL code (1101) identifies the transaction as a Cash Sale that belongs in the Cash Inflow subsection of the section of the Cash Flow Statement section, Net Cash from Daily Operations. The first "1" of the SL code stands for the Net Cash from Operations section. The second "1" stands for the Cash Inflow subsection and the "01" designation identifies this transaction as a Cash Sale.

Volume X, No. 2, 2009

\section{VARIABLE/FIXED COST CODING}

In order to provide management with information ready for use in decision making, it will be necessary for the coding system to identify variable cost from fixed costs. In the previous coding schemes that were presented, fixed and variable costs were not identified. In order to identify fixed versus variable costs, it is necessary to add an additional code field. This can simply be done by adding one extra digit to the code to be used for this purpose. In this one digit field, 1 would stand for a variable cost and 2 would stand for a fixed cost.

To properly code each cost transaction, the responsible manager or person must identify on the input document whether a cost is fixed or variable. The person providing this information in the transaction document must already be aware of what costs are fixed and what costs are variable. The output from the system will only be as good as the data fed into it. If the proper identifications are not made on the front end, it does not matter that we place a fixed or variable code on the cost. The coding is there to help process the data into the proper format to help decision making and not to tell managers who are unaware the difference between a variable cost and a fixed cost. The reports from the accounting system come after the fact and are only as good as the input. Strategic decision making becomes much more difficult if the variable versus fixed cost coding is not done. And it is even more difficult if it is not done properly. An example of this problem is the decision to eliminate a non profitable product in a multi-product plant. With traditional coding the financial report would be as indicated in Appendix VII.

With this typical example fixed costs and variable costs are not identified. The initial impression would be to assume that profits will increase by $\$ 80,000$. But this assumes that all the costs associated with product $\mathrm{A}$ will be eliminated by eliminating product A from the production mix. The reality is that the elimination of Product A will result in a profit decline. This would be readily apparent if the decision making report classified costs as to whether or not they are fixed or variable as in Appendix VIII.

The presentation in Appendix VIII shows that Product A is actually making a positive profit contribution to overall profitability and is absorbing $\$ 180,000$ in fixed costs. If Product $\mathrm{A}$ is eliminated product $\mathrm{B}$ will have to absorb all of the fixed costs now allocated to Product A. The net result for the elimination of Product A will be to lower overall 
profitability by the $\$ 180,000$ in fixed costs that Product $\mathrm{A}$ is absorbing. This is much more evident with the second presentation than the first.

\section{CONCLUSION}

The coding scenario presented above is not intended to be all inclusive. Rather, it is to show the types of analysis that must be done and the structure of the coding scheme that must be employed in order to do both financial and managerial reporting. It requires an in depth analysis of the company and the information needs of management. Strictly focusing on financial reporting and/or information will not allow a company's managers to make decisions with the proper information.

\section{REFERENCES}

1. Bodnar, George H. \& William S. Hopwood (2001). Accounting Information Systems (8th Edition). Upper Saddle River, NJ: Prentice Hall.

2. Carlton, F. et al (2005). Understanding the Impact of Enterprise Systems on Management Decision Making: An Agenda for Future Research. The Electronic Journal of Information Systems Evaluation, Vol. 8, No. 2, pp. 99-106.

3. Carter, William K. \& Milton F. Usry (1999). Cost Accounting (12th Edition). Houston, TX: Publications, Inc.

4. Folk, Jennie, Ray H. Garrison \& Eric W. Noreen (2002). Managerial Accounting (9th Edition). New York, NY: McGraw-Hill/Irwin.

5. Galway, L. A. and Hanks, C. H. (1996). Data Quality Problems in Army Logistics. Rand, Santa Monica, CA.

6. Garrison, Ray H., Noreen, Eric W., and Peter Brewer (2006) Managerial Accounting (11th Edition) Irwin McGraw, New York, New York.

7. Gelinas, Ulric J., Jr. \& Steven G. Sutton (2002). Accounting Information Systems (5th Edition). 5101 Madison Road, Cincinnati, OH 45227: Southwestern College Publishing Company.
8. Hall, James A. (2001). Accounting Information Systems (3rd Edition). 5101 Madison Road, Cincinnati, OH 45227: Southwestern College Publishing/Thomson Learning.

9. Hilton, Ronald W. (1997). Managerial Accounting (3rd Edition). New York, NY: McGraw-Hill.

10. Homburg, V. and Bekkers, V. (2002). The BackOffice of E-Government. Proceedings of the $35^{\text {th }}$ Hawaii International Conference on Information Systems, (9 pages).

11. Horngren, Charles, George Foster and Srikant Datar (2006). Cost Accounting: A Managerial Emphasis (12th Edition). Upper Saddle River, NJ: Prentice Hall.

12. Jiambalvo, James (2004). Managerial Accounting. New York, NY: John Wiley \& Sons, Inc.

13. McWatters, Cheryl S., Dale C. Morse and Jerold L. Zimmerman (2001). Managerial Accounting: Analysis and Interpretation (2nd Edition). New York, NY: McGraw-Hill/Irwin.

14. Moscove, Stephen A., Mark A. Simkin \& Nancy A. Bagranoff (2001). Core Concepts of Accounting Information Systems (7th Edition). New York, NY: John Wiley \& Sons, Inc.

15. Rockart, J. (2004). Information: Let's Get It Right. MIS Quarterly Executive, (3:3), pp. 143150.

16. Rogers, P. and Blenko, M. (2006), How Clear Decision Roles Enhance Organizational Performance. Harvard Business Review, (January), pp. 53-61.

17. Wimmer, M. R. et al (2001). Electronic Business Invading Public Sector: Considerations on Change and Design. Proceedings of the 34th Hawaii International Conference on System Sciences, (10 pages).

18. Weygandt, Jerry J., Donald E. Kieso and Paul E. Kimmel (2005). Managerial Accounting: Tools for Business Decision Making (2nd Edition). New York, NY: McGraw-Hill/Irwin. 
Appendix I

Organization Chart of Rwood Company (December 31, 20XX)

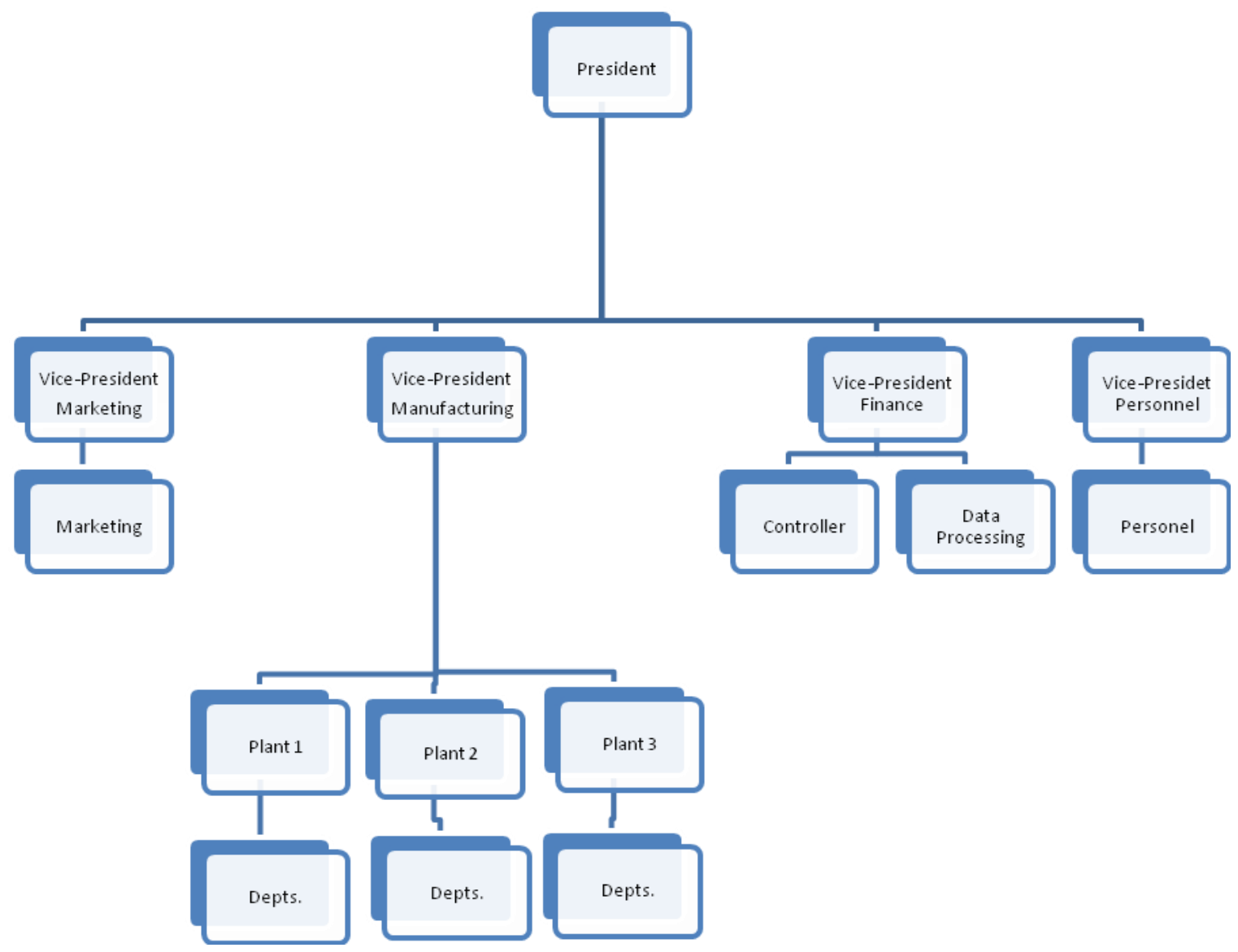




\section{$\underline{\text { Appendix II }}$}

Rwood Company

Plant Departments and Codes

$\begin{array}{ll}\text { Department } & \text { Code } \\ \text { Plant Manager } & 01 \\ \text { Accounting } & 02 \\ \text { Payroll } & 03 \\ \text { Data Processing } & 04 \\ \text { Product Design } & 05 \\ \text { Customer Service } & 06 \\ \text { Personnel } & 07 \\ \text { Production Scheduling } & 08 \\ \text { Raw Material Warehouse } & 09 \\ \text { Finished Goods Warehouse } & 10 \\ \text { Cutting } & 11 \\ \text { Sewing } & 12 \\ \text { Finishing } & 13\end{array}$

\section{Appendix III}

Rwood Company

General Ledger Subsections and Code

$\begin{array}{ll}\text { Subsection } & \text { Code } \\ & \\ \text { Current Assets } & 100 \\ \text { Long-Term Assets } & 200 \\ \text { Current Liabilities } & 300 \\ \text { Long-Term Liabilities } & 400 \\ \text { Owner Equity } & 500 \\ \text { Revenue } & 600 \\ \text { Cost of Sales } & 700 \\ \text { Operating Expenses } & 800 \\ \text { Other Gains and Losses } & 900\end{array}$

\section{Appendix IV}

Plant 3

Product Codes

$\begin{array}{lr}\text { Products } & \text { Code } \\ \text { Slips } & 1 \\ \text { Half Slips } & 2 \\ \text { Muumuus } & 3 \\ \text { Peignoirs } & 4\end{array}$


Appendix V

Plant 3
Slips
Size Codes

$\begin{array}{ll}\text { Sizes } & \text { Code } \\ \text { Small } & 1 \\ \text { Medium } & 2 \\ \text { Large } & 3 \\ \text { Extra Large } & 4\end{array}$

Appendix VI

Plant 3
Slips
Color Codes

$\begin{array}{lc}\text { Color } & \text { Code } \\ \text { White } & 1 \\ \text { Black } & 2 \\ \text { Ecru } & 3\end{array}$




\begin{tabular}{|c|c|c|c|}
\hline & FOR THE & $\begin{array}{l}\text { ppendix VII } \\
\text { ME STATEMH } \\
\text { AR ENDING }\end{array}$ & \\
\hline & Product A & Product B & $\underline{\text { Total }}$ \\
\hline Sales & $\$ 400,000$ & $\$ 3,000,000$ & $\$ 3,400,000$ \\
\hline Direct Labor & 180,000 & 400,000 & 580,000 \\
\hline Direct Materials & 40,000 & 460,000 & 500,000 \\
\hline Allocated Depreciation & 60,000 & 240,000 & 300,000 \\
\hline Cost of Goods Produced & $\$ 280,000$ & $\$ 1,100,000$ & $\$ 1,380,000$ \\
\hline Gross Profit Margin & $\$ 120,000$ & $\$ 1,900,000$ & $\$ 2,020,000$ \\
\hline Allocated Costs & 200,000 & 800,000 & $1,000,000$ \\
\hline Net Product Profit (loss) & $\$(80,000)$ & $\$ 1,100,000$ & $\underline{\$ 1,020,000}$ \\
\hline & FOR THE & $\begin{array}{l}\text { ppendix VIII } \\
\text { ME STATEMH } \\
\text { AR ENDING }\end{array}$ & \\
\hline & Product A & Product B & $\underline{\text { Total }}$ \\
\hline Sales & $\$ 400,000$ & $\$ 3,000,000$ & $\$ 3,400,000$ \\
\hline Less Variable Costs & & & \\
\hline Direct Labor & 180,000 & 400,000 & 580,000 \\
\hline Direct Materials & 40,000 & 460,000 & 500,000 \\
\hline Contribution & $\overline{\$ 180,000}$ & $\overline{\$ 2,140,000}$ & $\overline{\$ 2,320,000}$ \\
\hline Less Fixed Costs & & & \\
\hline Allocated Depreciation & 60,000 & 240,000 & 300,000 \\
\hline Allocated Costs & 200,000 & 800,000 & $1,000,000$ \\
\hline Net Product Profit (loss) & $\$(80,000)$ & $\$ 1,100,000$ & $\$ \$ 1,020,000$ \\
\hline
\end{tabular}

